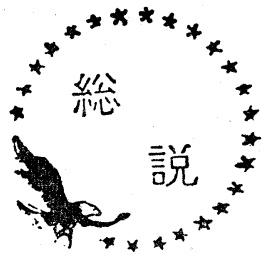

1. はしがき

NSU-バンケル型ロータリーエンジンの試作成功 が，はじめて公表されてから約 8 年を経過した。この 間には NSU, バンケル両社を含め, 泄界で18社が開 発グループに加わり，それぞれの応用分野における実 用化をめざし開発努力を続けている。したがつて，そ の開発状況はきわめて多岐にわたり, 多彩な成果を挙 げてきた。

表 1 NSU-バンケル型ロータリーエンジン 提携社名

\begin{tabular}{|c|c|c|c|c|}
\hline 社 & & 国 & 名 & \\
\hline NSU & 西 & ド & 1 & ツ \\
\hline Wankel & \multicolumn{4}{|c|}{$"$} \\
\hline Curtiss-Wright & ア & $x$ & リ & 力 \\
\hline ヤンマーディーゼル & 日 & & & 本 \\
\hline 巢染 T 業 & \multicolumn{4}{|c|}{ " } \\
\hline Perkins & 1 & ギ & リ & x \\
\hline Fichtel \& Sachs & 西 & F゙ & 1 & ツ \\
\hline Daimler-Benz & \multicolumn{4}{|c|}{$" \prime$} \\
\hline Klöckner-Humboldt-Deutz & \multicolumn{4}{|c|}{ " } \\
\hline MAN & \multicolumn{4}{|c|}{ " } \\
\hline Krupp & \multicolumn{4}{|c|}{ " } \\
\hline Rheinstahl Hanomag & \multicolumn{4}{|c|}{ " } \\
\hline Alfa Romeo & 1 & 夕夕 & リ & ア \\
\hline VVB Automobilbau & 東 & ド & 1 & ッ \\
\hline Rolls-Royce & 1 & ギ & リ & x \\
\hline Porsche & 西 & ド & 1 & ッ \\
\hline Outboard Marine Corp. & $\gamma$ & $x$ & リ) & カ \\
\hline Comotor S. A. & \multicolumn{4}{|c|}{ ルクセンブルグ } \\
\hline
\end{tabular}

このらちすでに企業化段階にはいつたロータリ ーエンジンは, NSU 社が 1962 年秋の小型ボート 用水冷エンジン生産開始を皮切りに，1964年 9 月 にはスポーツカー用 1 ローターエンジン，1967年 秋には図 1 亿示寸外観の乗用車用 2 ローターエン ジンと相ついで市販を行なつてきた ${ }^{122)}$ 。 また Fichtel \& Sachs 社は, 図 2 (a) に示寸汎用空
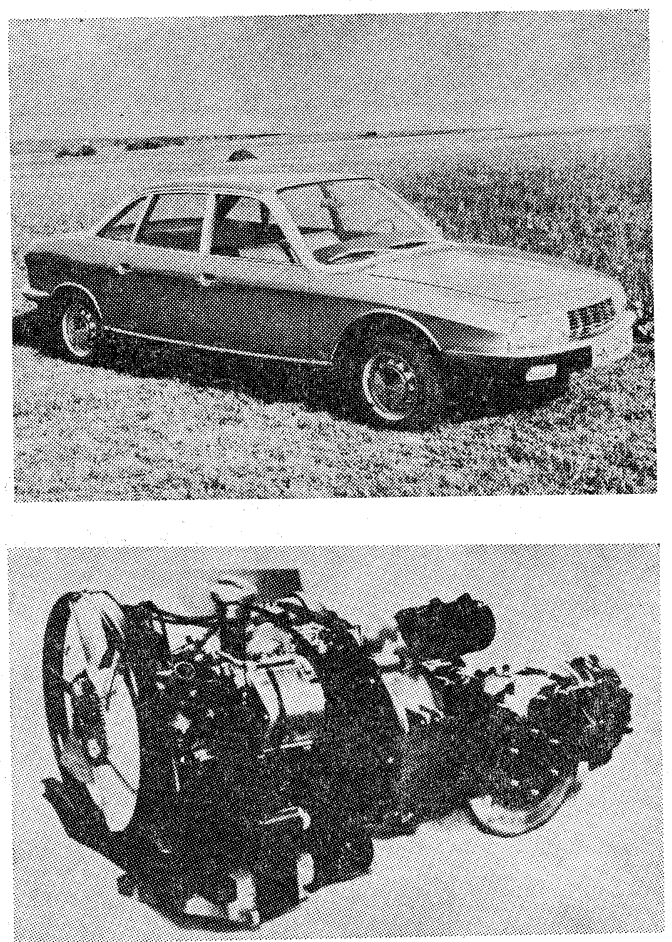

図 1 ロータリーエンジンを塔載した NSU $\mathbf{R}_{0} 80$ (上); NSU KKM 612 型ロータリーエンジン 外観 (下)

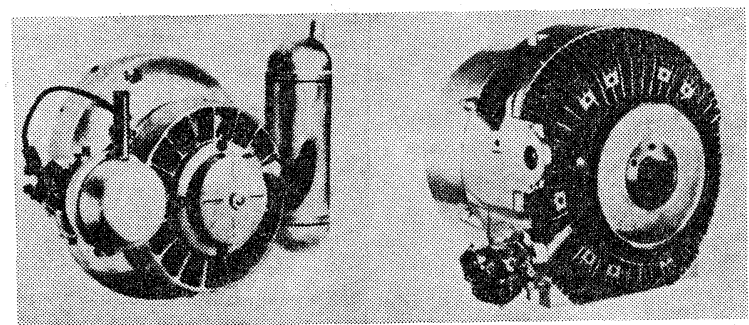

(a)

(b)

排気量 : $108 \mathrm{cc}$

排気量 : $300 \mathrm{cc}$

最大出力 $: 6.5$ 最大出力 : 18PS/

$\mathrm{PS} / 6,500 \mathrm{rpm}$

$5,500 \mathrm{rpm}$

図 2 Fichtel \& Sachs 社空冷ロータリーエンジン 

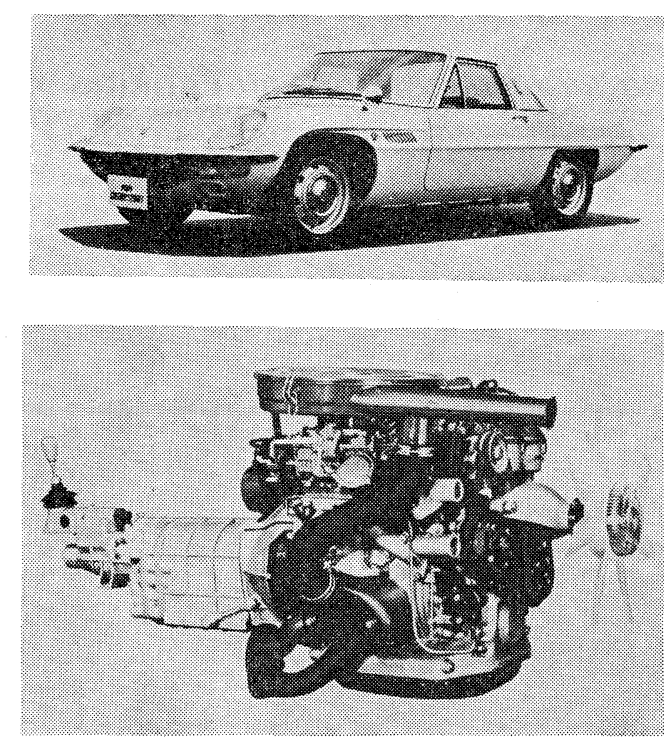

(a)

上：コスモスポーツ外観

下：同上塔載エンジン
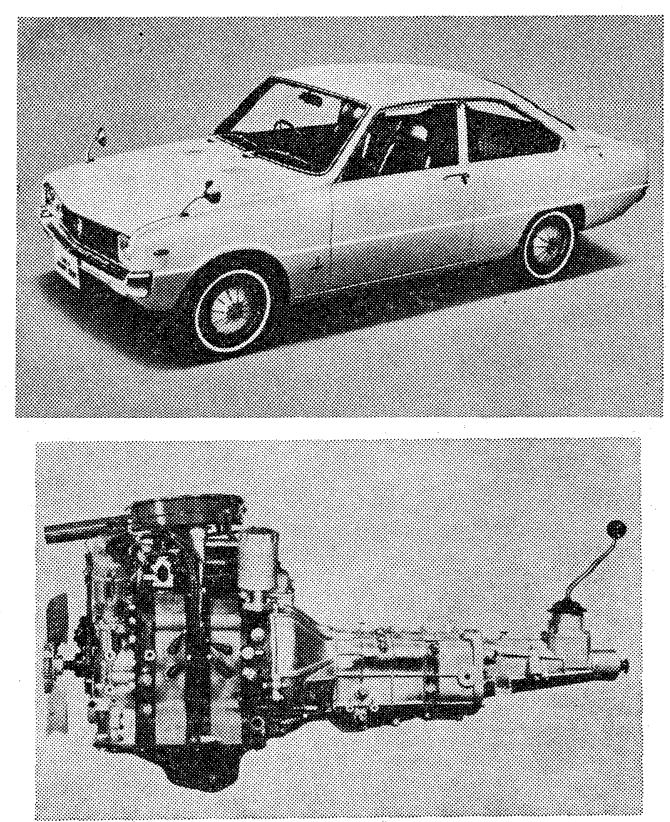

(b)

上：ファミリア・ロータリー・クーペ・外観

下：同上塔載エンジン

図 3 東洋工業におけるロータリーエンジン塔載車

冷小型エンジンから図 2 (b) にみるようなエンジンへ としだいに生産機種の拡充をはかりつつある3”。

一方わが国においても東洋工業が1967年 6 月, 2 口 ーターエンジンを搭載した「コスモ・スポーツ」の市 販開始に引続き，1968年 7 月には「ファミリア・ロー タリー・クーペ」搭載エンジンの本格的生産が始まる など，ロータリーエンジン実用化のテンポは急速な高
まりをみせている。

以下最近の自動車用エンジンを主体に，その構造概 略と技術的進歩の一端を紹介する。

\section{2 , 出力性能}

表 2 と図 4 から図 6 亿主要諸元と全開出力性能を示 した。

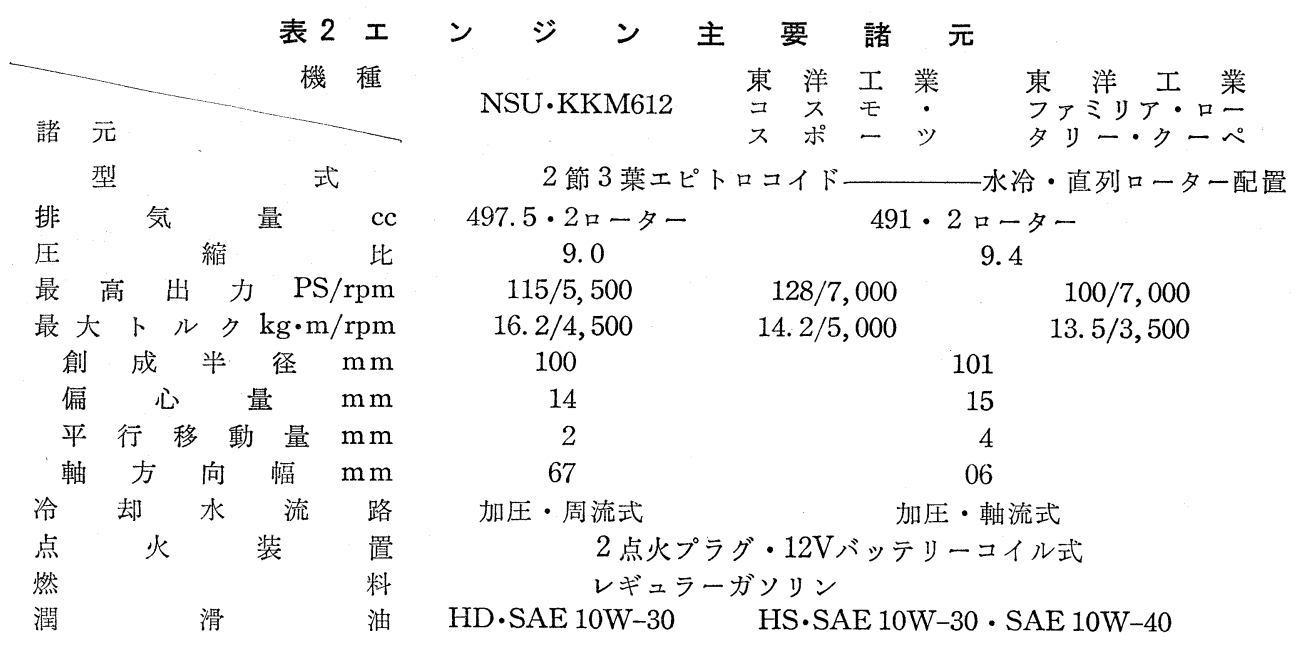




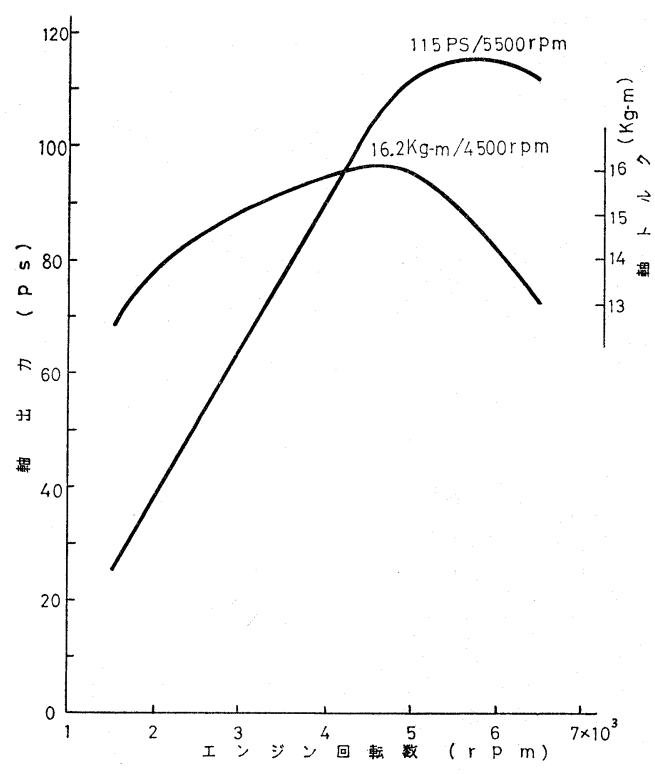

図 4 KKM 612 エンジン性能曲線 (NSU)

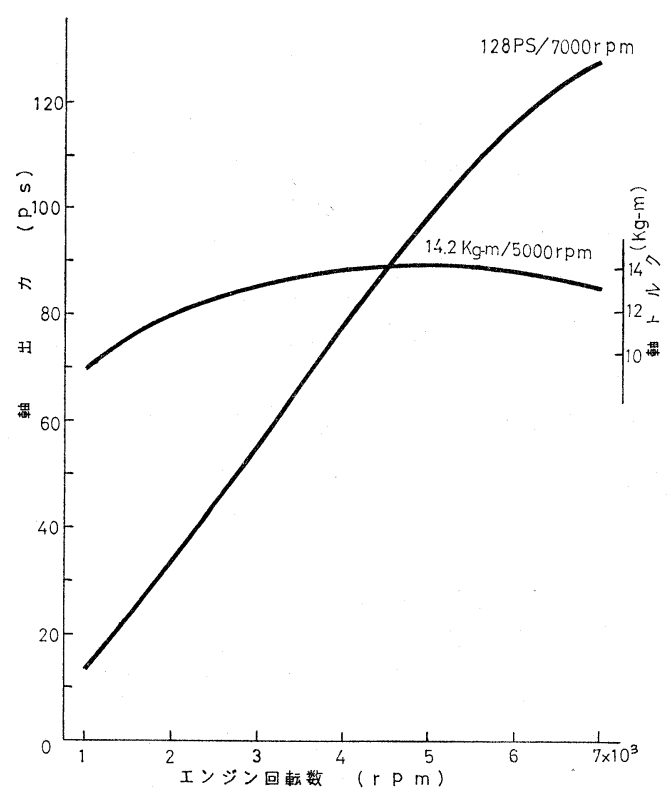

図 5 コスモ・スポーツエンジン性能曲線(東洋工業)

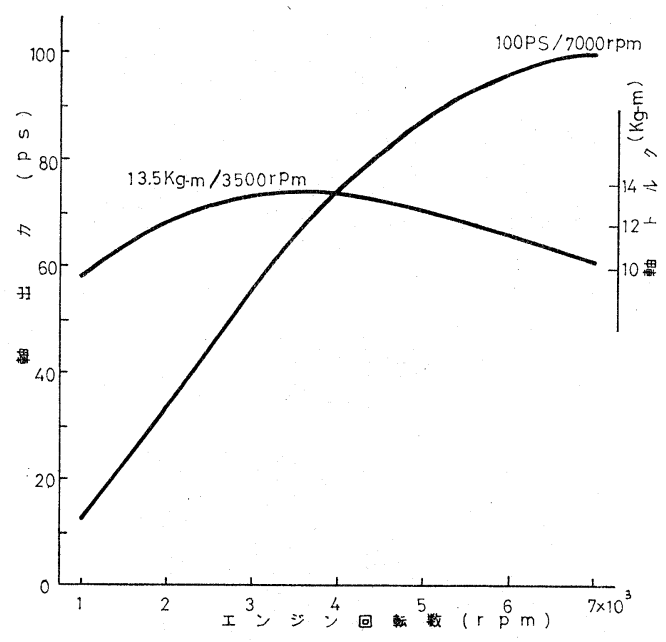

図 6 ファミリア・ロータリー・クーペエンジン性能 曲線（東洋工業）

東洋工業の場合，いわゆるNSU-バンケル型ロータ リーエンジンの生産発売が日本で最初であり, しかも なお，海外における過去の実績がきわめて限られてい るといら事情から, 要求される諸要素のらち, 而久性 信頼性を最重視した 構造をエンジン開発の基本にし た。したがつて出力性能は, いたずらな高性能の追求 でなく, 柔軟な運転性状, 乗りやすい性格の実現にポ イントが置かれている。

ここで, これらロータリーエンジンの大きなメリッ トとされるコンパクトさを，エンジン重量の面からレ シプロエンジンと比較して表 3 亿示す。比較対象とし たレシプロエンジンは 90〜130 PS の出力をもつ国産 エンジン11例の平均值である。

\section{3. ローター配列}

乗用車用エンジンとして強く望まれる運転の容易 さ，あるいは振動・騒音などの点からエンジン・トル ク変動に注目した結果, NSU 社東洋工業いずれも直 列 2 ローター方式を採用している。

2 ローターエンジンの出力軸であるエキセントリッ ク・シャフトは図 7 の外観, あるいは図 8 (a) の縦断

\section{表 3 自動車用エンジンとしての重量比較}

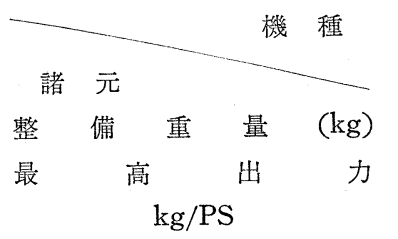

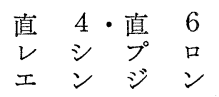

180

103

1.75

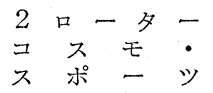

108

128

0.84

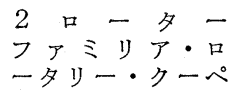

122

100

1. 22 


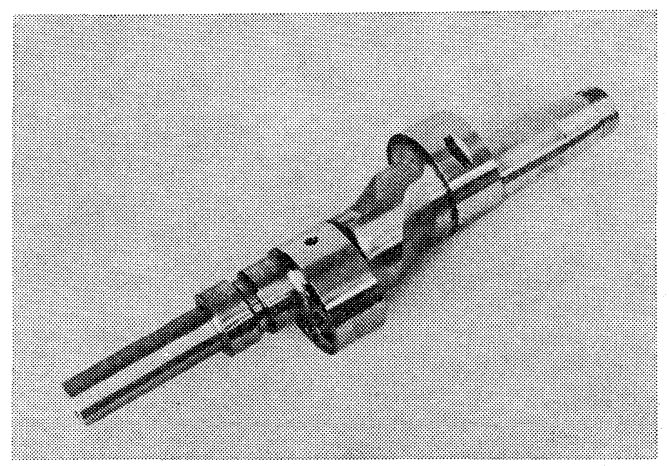

図 72 ローターエンジンエキセントリックシャフト (東洋工業)

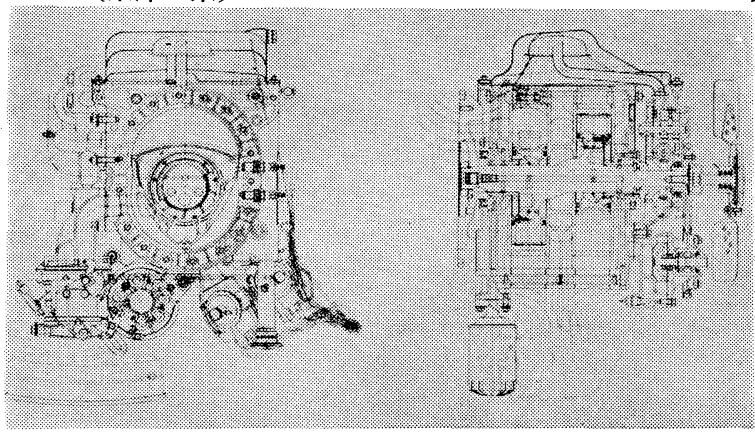

(a)

図 8 ファミリア・ロータリー・クーペ塔載エンジン構造図

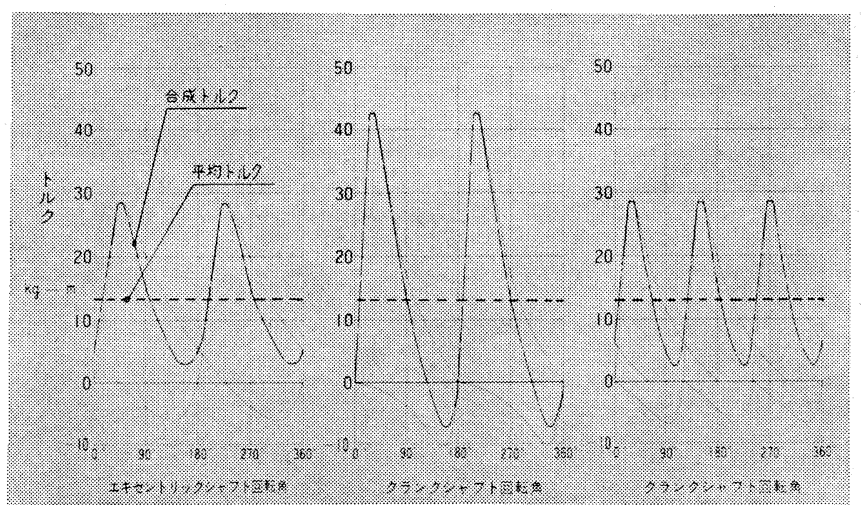

(a) 2 ローター エンジン

(b) 直 -4 気筒レシ プロエンジン

(c) 直-6 気筒レシ プロテンジン
図 9 トルク变動特性の比較図

面構造図からわかるように，180の位相で設けた $2 つ$ の偏心輪部分（クランク・ピン相当）でそれぞれロー ターをささえている。そこで $180^{\circ}$ 間隔で点火される口 ータリーエンジンの各作動サイクルは, この出力軸回 転角で $270^{\circ}$ にわたるという特異さから，2ローターエ ンジンの前後ローターの爆発過程にはオーバーラップ
を生じ，合成トルクは図 9 (a) のごとくマイナス領域 を示すことがない。この結果，2ローターエンジンの トルク変動特性は図 9 (b) の 4 気筒レシプロエンジン より,むしろ図 9 (c) に示した直列 6 気筒エンジンの それに近い特性をもつ。

完全バランスが図れる回転メカニズムを主体とする 構造上の有利さに加え, 滑らかな回転特性をもつ NS Uーバンケル型ロータリーエンジンは，コンパクトさ と使い易さがとくに望まれる自動車用エンジンの分野 で高い評価を受ける一要因といえよう。

\section{4. ハウジング}

レシプロエンジンのシリンダブロック，シリンダヘ ッドに相当するエンジン・ハウジングについて，東洋 工業「ファミリア・ロータリー・クーペ」の例を図10 に示す。

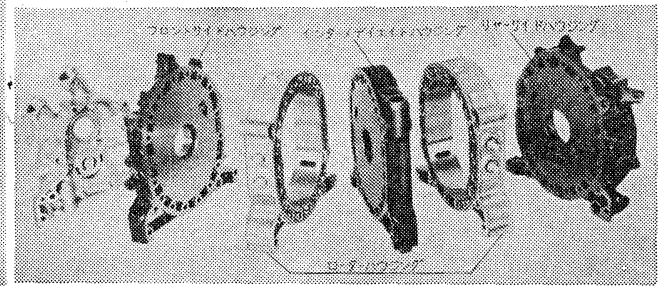

図 102 ローターエンジンハウジング構 成（東洋工業）

ローターハウジングは放熱効果を主体 にした観点からアルミ合金製で，トロコ イド軌道面は硬質クロームメッキが施さ れ，倣い研削仕上げである。

一方, サイドハウジングは生産性を考 慮した結果, シエルモールド鋳造の薄肉 鋳鉄製で，その側壁摺動面は高周波焼入 を行ない, 酎摩耗性と生産性を両立させ ている。

むろん, これらハウジング素材材質, 耐摩耗表面処理はエンジン性能を主体と する運転条件に関連づけて決定される。 この意味から純然たるスポーツカーとし て一層過酷な使用状況の連続が予想され る「コスモ・スポーツ」の場合は, サイドハウジング も冷却効果にすぐれたアルミ合金製とし，その側壁摺 動面は熱的および拆接負荷条件を勘案して高炭素鋼と モリブデン材の金属熔射被覆を施すなど, 耐久性確保 には細心の留意を施してある。

図12に摩耗傾向の実測例を示す。 


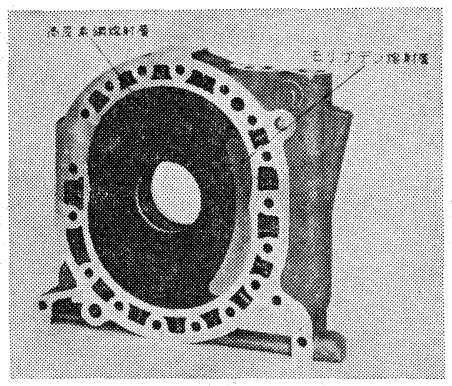

図 11 モリブデン 高炭素鋼溶射被覆層を 採用したサ イドハウジング（東洋工業）

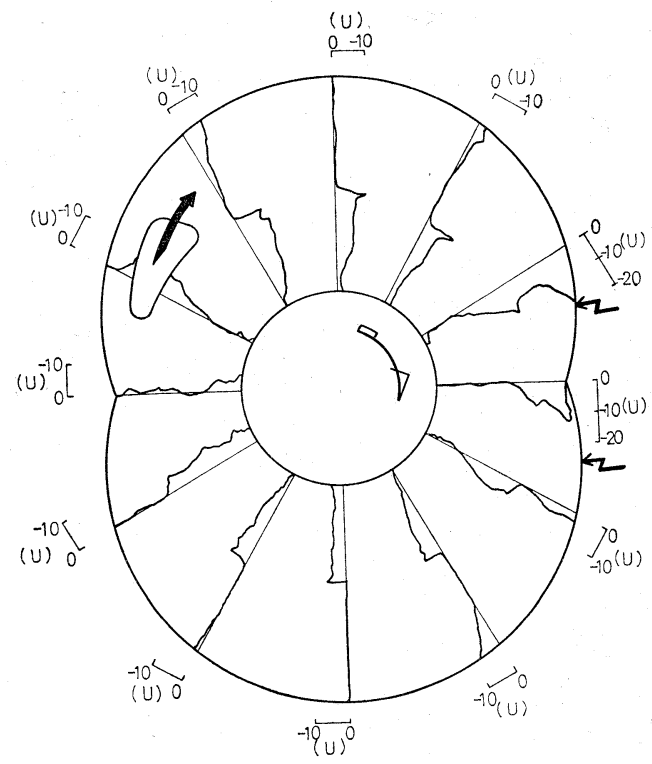

図 12 サイドハウジングの 摩耗 10 万 $\mathrm{km}$ 走行後 （東洋工業）

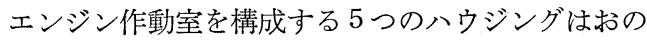
おのダウエルピン，テンションボルトを併用したサン ドイッチ構造で均質な締付け面圧を保ち, 熱膨脹に対 忘させてある。

\section{5. ガスシール}

エンジンのガスシール，とりわけアペックスシール は気密性, 耐久性の点で NSU-バンケル型ロータリー エンジンの最大の問題点であつたといえる。すなわ ち，開発初期に使用されていた金属シールではトロコ イド軌道面に波状痕を伴う異常摩耗を発生し，エンジ ン耐久性を限定する大きな要素となつていた。摩擦振 動に起因するこの波状摩耗は, 東洋工業の場合, 自己 潤滑性をもち，振動減衰能にすぐれた特殊カーボンシ ール材を開発し，それに適合するトロコイド面材料の

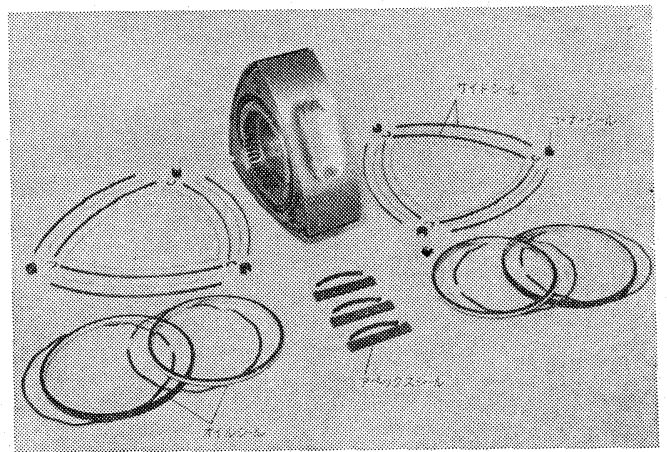

図 13 ガス・オイル シール エレメント（東洋エ業）

選定によつて完全に解決された。これらカーボンシー ルの実用化にあたつては, 広範囲の強度試験と非破壊 検査による品質管理が行なわれ，信頼性が確保されて いる。ちなみに, カーボンシールの摩耗は走行 1 万キ ロ当たり $0.07 \sim 0.1 \mathrm{~mm}$ の範囲にあり，トロコイド面 クロームメッキ層の摩耗はほとんど無視できる程小さ い。

一方，NSU社はトロコイド軌道面に Elnisil と呼ぶ プロセスを採用し，シリコンカーバイドの粉末を添加 したニッケルメッキで高硬度層を確保し，特殊鋳鉄ア ペックスシールとの組合わせで好結果を得ているとい われる。

半径方向に 2 重配置とし，ラビリンス効果によりシ ール性能を高めたサイドシールには，アペックスシー ルほどの困難さはなく，シール断面形状の選定に注意 し，シール溝壁とサイドハウジング側壁面の間との接 触に確実さを期してある。使用材質はピストンリング 鋳鉄である。

これらガスシール部分の潤滑は, 減摩作用と同時に 油膜を媒体とする気密保持の点から重要である。当初 のテストエンジンでは $50: 1$ ないし $100: 1$ 程度の混 合油然料を用いたり, ロータ一側面からの洩れオイル 量を適当にコントロールする方式などが用いられた が，実用面における不便さ，困難さから現在は主とし て可変ストロークのプランジャタイプ・メータリング ポンプを使用し，エンジン回転数および負荷に応じて 計量されたオイルを吸気系統の特定の場所から吸入さ せる《分離給油システム》が採用されている。

図14には吸気マニホルド中に噴き込まれるメータリ ングオイル送給特性の例を示す。

これらメータリングオイルを含めたオイル消費率は 平均 $2,000 \sim 3,000 \mathrm{~km} / l$ であり, 同出力クラス 4 サイクルレシプロエンジンとほぼ同水準にあるといえ 


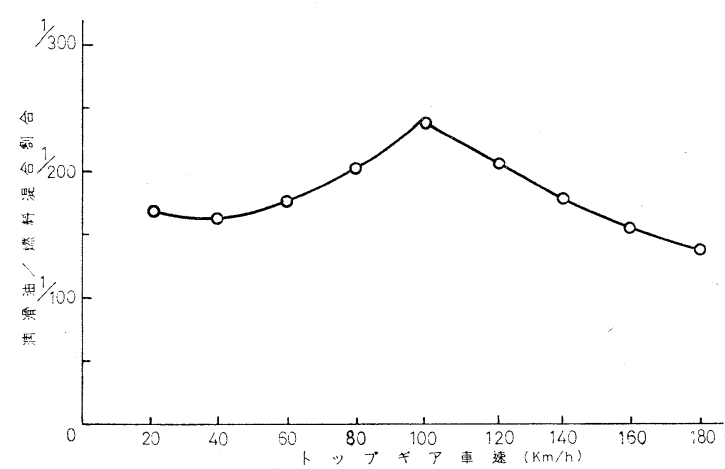

図 14 定常走行時 (トップギア)メータリングオイ ル送給特性（東洋工業）

る。

\section{6. オイルシール}

一般にローター冷却はその内部に潤滑オイルの一部 を循環させるため，オイルシールはガスシールととも に開発当初から解決の難しい問題であつた。しかし， 今日ではシール性能が飛躍的に改善され, 実用上十分 な域に到達した。

現用されているオイルシール型式は大別してつぎの 2 型式に分けられる。すなわち,

(a) ローターとサイドハウジングの間でシールす る形式。

（b） 主としてローターとエキセントリック・シャ フトの間でシールする形式 ${ }^{4}$

で，それぞれの代表的な構造例を図15 (a，b) に示す。

(a) は東洋工業が採用したオイルシール形式である。 ローターの両側面にオイルかきリングを 2 重に配置 し，それぞれのリングは底に敷かれた波状バネによつ

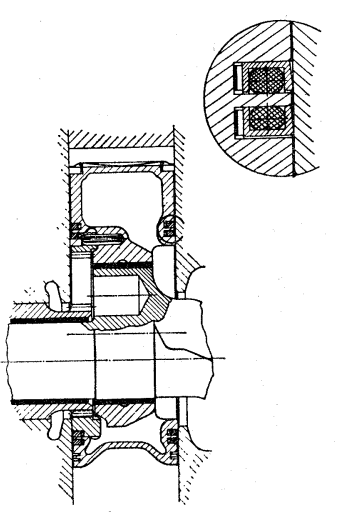

(a)

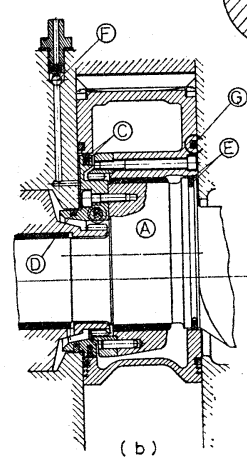

図 15 オイルシール構造
てサイドハウジングに一定荷重で押しつけられ，テ ーパー状のリップ部によつてオイルかき取り作用を 行なわせている。この場合, シール内外径面いずれ かに“O”リングを挿入し，シール溝背隙からのオ イル洩れを防止する構造である。

この形式はオイルシールがローターとともに遊星 運動を行ないながら，サイドハウジングの面を㧵動 するため，サイドハウジングの平面度，材質がシ一 ル性能とシールリップ摩耗に関連する困難さはある ものの，構造が単純で応用範囲が広い特徴がある。

これに対し，(b) は NSU 社が開発したオイルシ 一ル構造で, シールは主としてローターとエキセン トリック・シャフトの間で行なわれる。シャフト偏心 輪部分 (A) にローターと同心の円板 (B) を取り付け, この円板外周溝に 2 枚 1 組のピストンリング $(\mathrm{C})$ を挿 入し，ローター片側内径面に張らせている。また，こ の円板の軸方向端部はサイドハウジング 内径と同心 で，その部分にもピストンリング (D) を用いサイド ハウジング内径面に張力を与えてある。いま一つの口 一ター片側内径面に対しては，円板の代りに偏心輪部 分に円周溝を設け，この溝中に 2 枚 1 組のピストンリ ング (E) を挿入し，ローター内径面に張らせてあ る。

これはサイドシールから洩れたガス圧力で各ピスト ンリングをそれぞれの溝壁に押し付け，シール作用を 受持たせる構造である。したがつてピストンリングに 加わるガス圧力が極度に高くなると，駆動抵抗の増加 をもたらし，ピストンリングとそれぞれの溝壁の摩耗 が問題となるところから，これらシールリングに作用 するガス圧力を約 $0.2 \mathrm{~kg} / \mathrm{cm}^{2}$ 以下に保つためのリリ 一フ弁 (F) を用いている。さらにガス圧力がゼロと なるエンジン停止時, オイルがピストンリング間隙を 通つて燃焼室に洩れるのを防止するには，ロータ一側 面のサイドシール内側に波状バネを背面に使用したフ ェイスシール（G）を設けている。

こうしたシール形式はサイドハウジングの平面度に 無関係で, シール構造体の主要部分が同心運動を行な らため安定した性能が得られる反面, 構造が複雑でサ イドシールを洩れたガス圧力がほとんど大気圧に近い サイドポートの吸気方式を採用したエンジンへの応用 は困難であるなどの欠点をもつている。

\section{7. 冷却}

7-1 ハウジング冷却

NSUーバンケル型ロータリーエンジンでは，各作動 過程がトロコイド軌道面の一定した場所で行なわれる 
ため，燃燒室付近の最高温度を下げるとともに，トロ コイド全周に沿つての温度差をできるだけ少なくする ことが重要である。

この意味から冷却水の流路設定, あるいは冷却フィ ンの設定には細かい配慮を必要とする。

図16に東洋工業におけるサイド八ウジング切断面の 一例を示した。多数のリブで仕切られた冷却水ジャケ

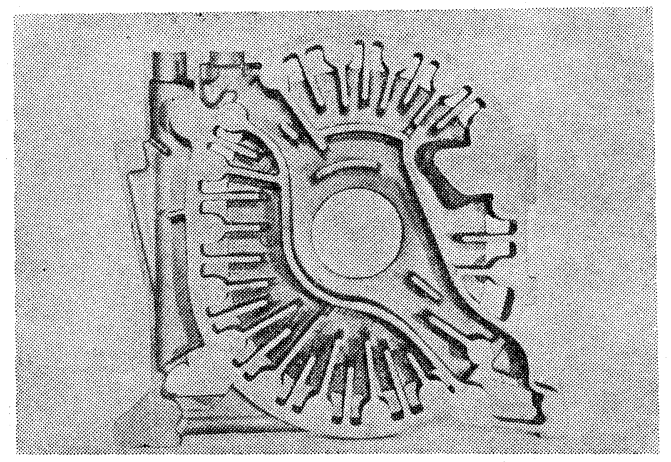

図 16 サイドハウジングウォータージャケット構造 （東洋工業）

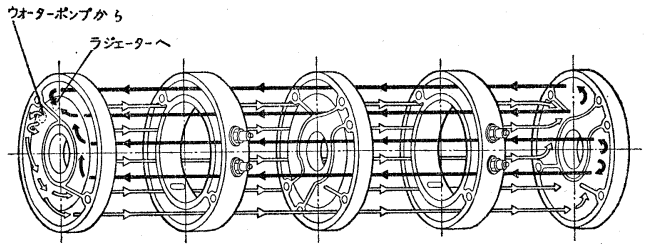

図 17 エンジン ハウジング 冷却水流路（東洋工業）

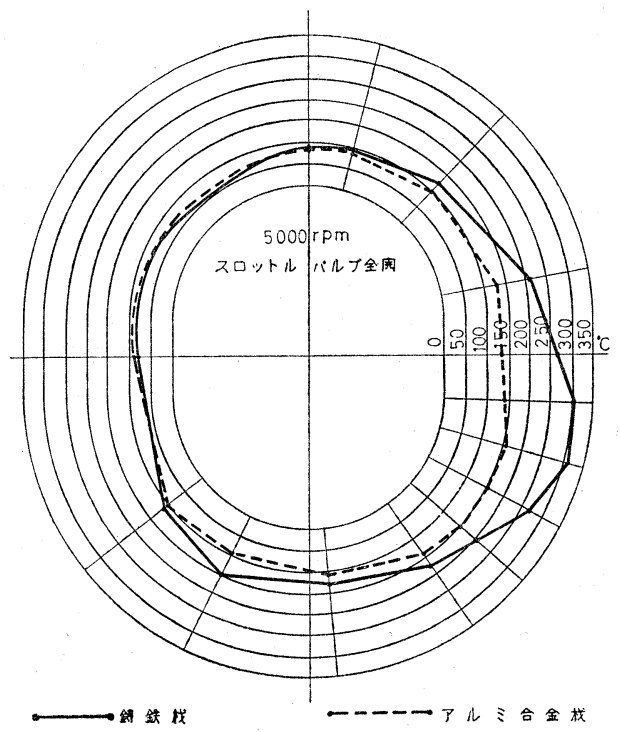

図 18 トロコイド軌道面温度の比較
ットは熱的負荷に応じて貫流する流速, 流量を変えて ある。

図17には同じく東洋工業の冷却水循環流路の大要を 示した。冷却水の主流はトロコイド軌道面の外周を軸 方向に流れ，反転往復する《アキシアル・フロー方 式》である。これら泠却系統はサブタンクを使用した $0.9 \mathrm{~kg} / \mathrm{cm}^{2}$ 加圧密封式で，カーヒーターを含めた全容 量は $7 l$ 。エンジン内部への水洩れ防止, ウォーターポ ンプシール部の保護と鳴き防止の役割りをするバーズ リークスを加えたロングライフ・クーラントを用い， クーラントの交換は 2 年もしくは $4 \mathrm{~km}$ 万としてメイ ンテナンスライフの延長，簡易化をはかつている。

図18はローターハウジングが鋳鉄の場合とアルミ合 金材の場合について，トロコイド面より $1 \mathrm{~mm}$ 離れた 位置に㧈ける温度分布の計測結果である。最高温度部 において錓鉄八ウジングはアルミ合金材に比べ約 150 ${ }^{\circ} \mathrm{C}$ 高く, すでに 潤滑油膜保持の限界温度を越えてい る。したがつて運転条件の過酷な エンジンに対して は，アルミ合金材八ウジングが温度的に有利である。 7-2 ロータ一冷却

自動車用エンジンなど比出力の高い場合, ローター 内部冷却は油泠式が採用されている。その循環機構は 図19のごとく、ローターの遊星運動によつてオイルに 働く慣性力の変化を巧みに利用したもので，自動的に 循環排出させている。

図20にローター冷却循環油量が出力, 燃費におよぼ す影響の一例を示す。最終的にはローターの熱変形や ガスシールの膠着（スティック）を防止し，オイル性 状の劣化を最小限に保ち得る限界油温を考慮しつつ， 出力，燃費の影響をバランスさせるなどの見地から循 環油量が決定されている。

また Fichtel \& Sachs 社では小型空冷エンジンに対 し，吸入混合気によってロータ一内部冷却を行ない成 功している。図21はその導入経路で, 吸入混合気は片 側のサイド八ウジングからローター内部に導かれ，軸

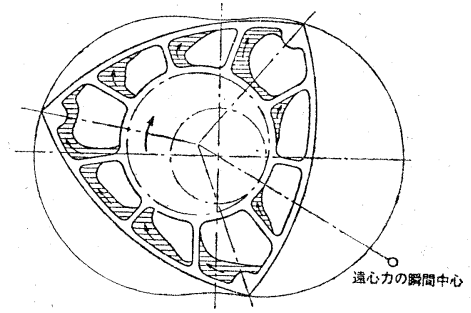

図 19 慣性力変化を利用したローター冷却 

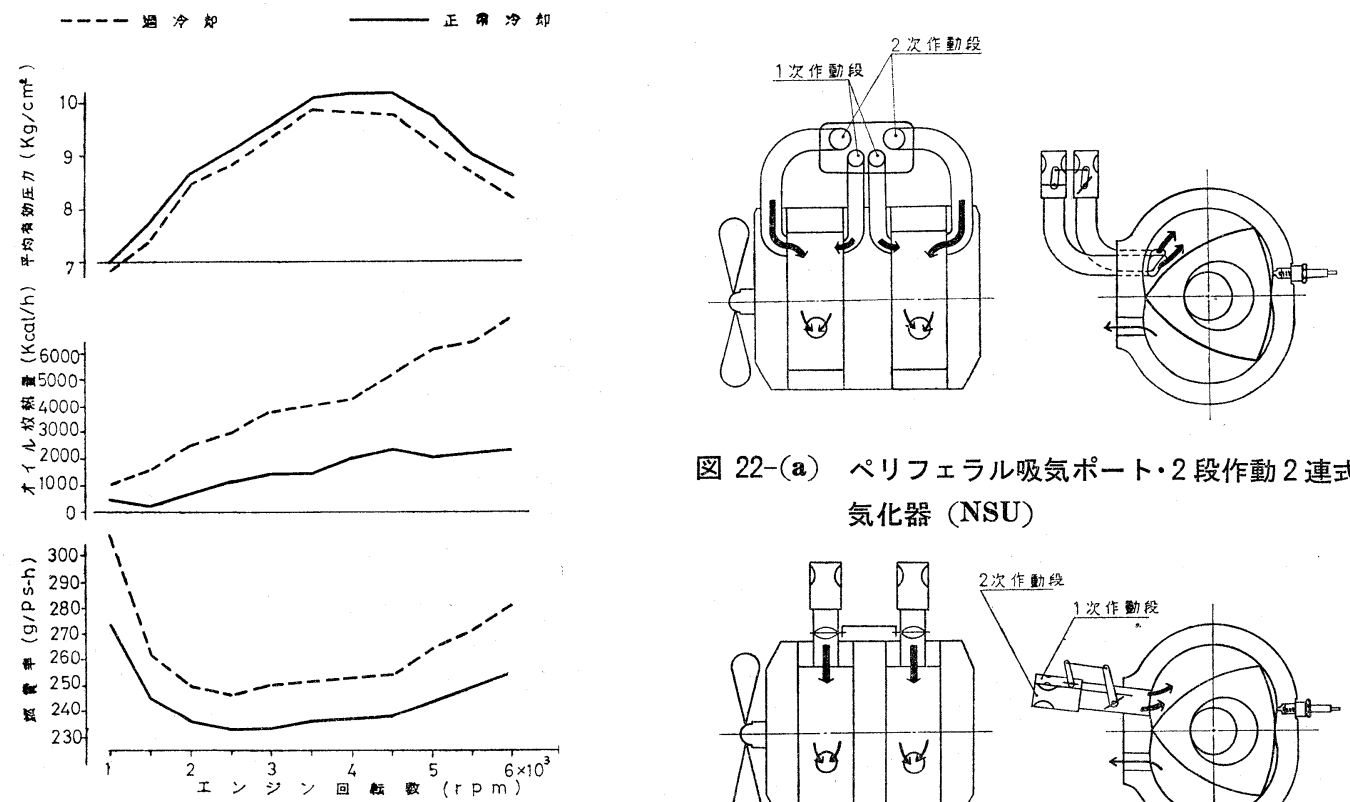

図 22-(a) ペリフェラル吸気ポート・2段作動 2 連式 気化器 (NSU)

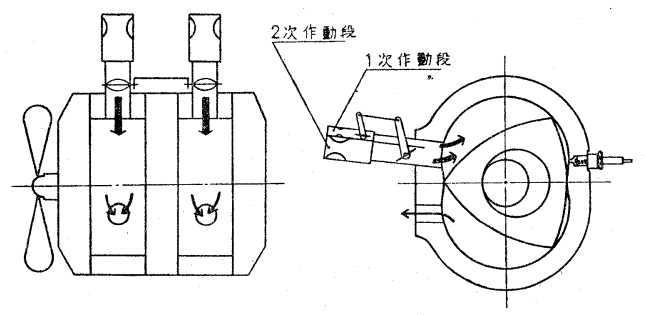

図 20 ローター冷却油量が性能・燃費におよぼす影響

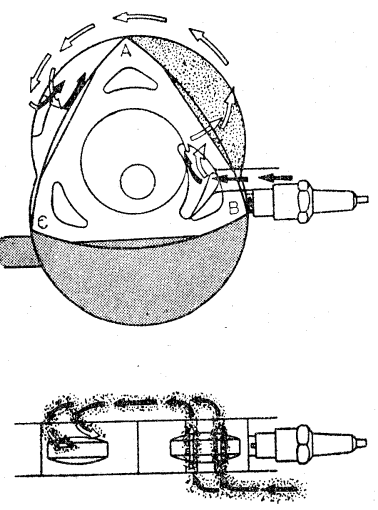

図 21 F \& S 社混合気導入経路図

方向に貫流して反対側のサイドハウジングに抜ける。 したがつて吸入混合気はローターから熱を奪うと同時 に予熱され，気化が促進されるという興味深い構造で ある。

\section{8. 吸気方式}

出力性能に密接な関連性をもつ吸気ポート配置に関 し，NSU社 KKM 612 エンジンではトロコイド軌道 面に開口するペリフェラルポートと 2 段作動 2 連式気 化器の組合わせを採用しているのに対し，東洋工業の 場合「コスモ・スポーツ」，「ファミリア・ロータリー ・クーペ」両エンジンとも各サイドハウジング側壁面 に吸気ポートを設けたサイドポート方式で，それぞれ
図 22-(b) サイド吸気 ポート・2 段作動 4 胴式 気化 器 (東洋工業)

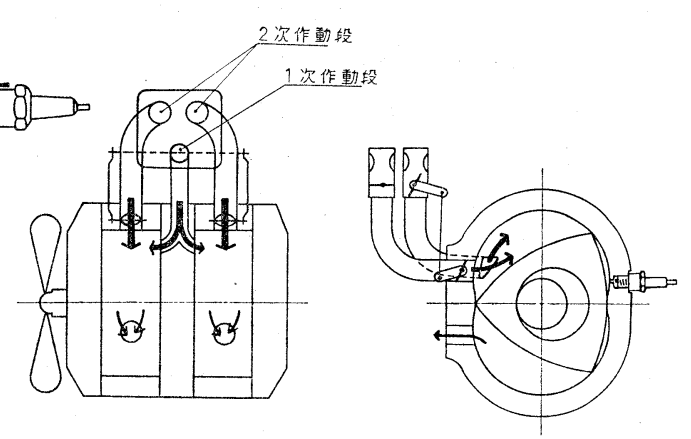

図 22-(c) コンビ吸気ポート・2 段作動 3 胴式気化 器 (東洋工業)

は常用軽負荷運転用としての一次側および高出力時一 次側と協働する二次側ガス流路を構成し，2段作動胴 式気化器と組合わせである。

図23にこれらサイドポートとペリフエラルポートの ポート開口時間面積経過ダイアグラムを示す。

一般にペリフエラル ポートは吸気時間面積が大き く，吸入抵抗が小さいので吸入效率が高く，かつ有効 圧縮比の向上が得られやすい反面，吸排気ポートが同 時に開口するポート・オーバーラップが大きくなり， アイドリングや部分負荷時に運転の安定性確保に難点 を生ずるこれに対してサイドポートは, 吸入ポートの 


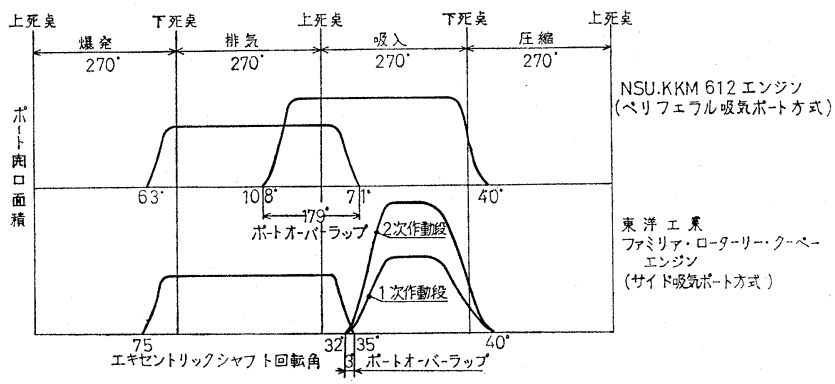

図 23 ポートタイミングと開口面積一時間経過の比較

開き始め時期が上死点後と幾何学的に遅くなるためオ 一バーラップが小さく, アイドリングや部分負荷性能 はペリフエラルポートに比べて著しく改善されるが， 屈曲したガス流路，ポート開口面積などから高負荷時 の吸入効率に制約を受ける。したがって基本的にペリ フェラルポートは高速高出力型エンジンに適し, サイ ドポートは低速部分負荷運転性を重視するエンジンに 適する傾向をもつといえよう。

むろん，これら両方式の長所を組合せたコンビポー 卜方式の研究もす寸められている（図 22 (c))。この 方式はたとえば 2 段作動 3 胴式気化器を用い, 一次側 がサイドポート，二次側がペリフエラルポートにつな がつている。さらに二次側ポート近くには一次側ス口 ットルバルブと連動するポートバルブが設けられ，軽 負荷運転ではサイドポートとして作動し，一次側ス口 ットルバルブが一定開度以上に開く高負荷時にのみポ ートバルブが開いて吸入効率のよいペリフエラルポー トの作動が追加される結果, アイドリングから高速重 負荷までの広沨な運転範囲で良好な性能を得ることが できる。

\section{9. 燃焼}

東洋工業においては自動車用エンジンとして最も重 要と考えられる比出力の向上と部分負荷時の燃費経済 性確保のため吸排気系統, 点火系統など燃焼室を含め た関連要素について種々の計測を行なつてきた。

図24は吸気ポート方式の相違が部分負荷燃焼におよ ぼす影響をみるため，イオンギャップを用い燃燒速度 のバラツキを統計的に記録した例である。部分負荷時 の燃焼安定性に関し, サイドポートはペリフエラルポ 一トより好ましい傾向にあることを裏付ける一例とい えよう。

図25にヒートバランス測定例を示す。また指圧線図 測定結果からポリトロープ指数は，ほぼ理論值に近い

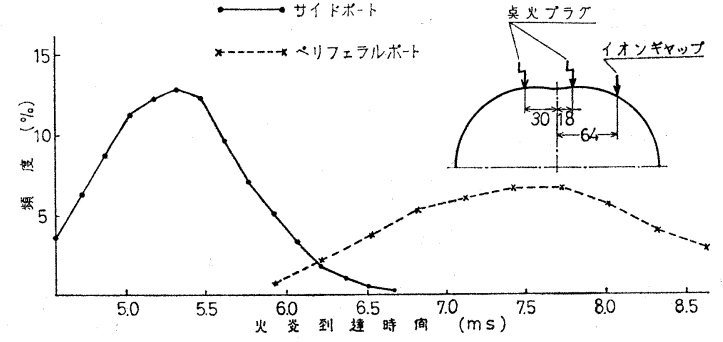

図 24 火炎伝播時間のバラッキ (1,000 rpm, Pe= $1.3 \mathrm{~kg} / \mathrm{cm}^{2}$ )（東洋工業）

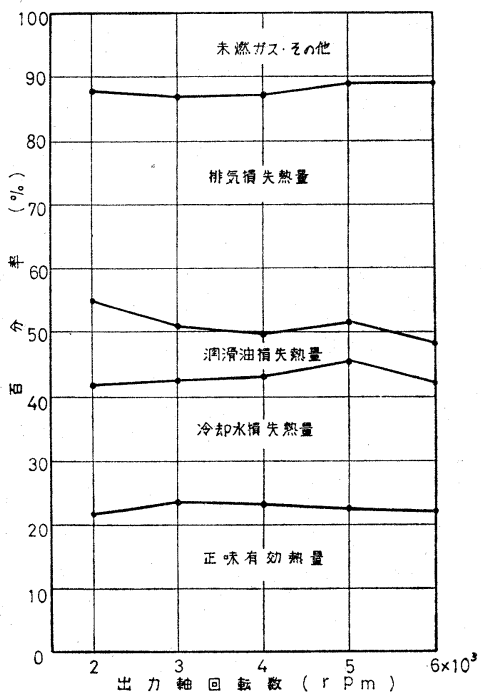

図 25 ヒートバランス（東洋工業）

ことが確認されている。

点火プラグ配置は図 8 (b) の横断面構造図にみるよ らトロコイド短軸をはさんで設けた 2 点火プラグ方式 でそそれぞれは独立した点火系統によつて点火される システムを採用した。1 点火プラグに比べ, 燃焼率, 
冷間始動性などを大幅に向上させる一つの要素となつ ている。

とはいえ, 単室容積 $490 \mathrm{cc}$ クラスの燃焼室は従来の 自動車用レシプロエンジンの概念からいつても大きい ほうに属し，また作動の特異さと相まつて，その燃焼 過程の本質についてはな打多くの不明確な点があり, 今後の研究にまつべき課題が残されている。

\section{0. 将来の展望}

NSU-バンケル型ロータリーエンジンは, 密度の濃 い開発研究によつて実用化を阻む多くの問題点をほと んど解決し, 自動車用エンジンをはじめとする各分野 でレシプロエンジンに十分対抗し得る耐久性, 信頼性
をもつ段階に到達した。

レシプロエンジンに比べ本質的に有利とされる, 軽 量小型, 幅広い回転レンジ, 振動騒音などの特徵をさ らに生かし, 現時点でなお限界を究めたといい難い, 低速域でのガスシール性能, 燃焼過程などの積極的な 改善をはかるならば，名実ともに備えた高速エンジン として一段とその真価を発揮することができよう。

\section{文献}

1) W. Froede, SAE Paper 650722, Oct. (1965)

2) W. Froede, SAE Paper 680461, May (1968)

3) H. Keller, $M T Z, 26,4,165$ (1965)

4) G. Jungbluth, $M T Z, 28,9,351$, (1967)

\title{
Rotary Piston Engine
}

\author{
by Kenichi Yamamoto \\ (Toyo Kogyo Co., Ltd.)
}

SYNOPSIS:-Eight years have gone by since the success of the proto-type NSUWankel rotary piston engine was announced. Today, a total of 18 organizations, including NSU and Wankel, are continuing efforts for the practical use of the Wankel engine in their respective fields, and commercialization and volume-production are progressing at an extremely quick tempo.

Developments of the Wankel engine have been remarkably progressed especially in the fields of portable engines for various uses, or automobile engines in which the merits of the Wankel engine are effective.

Future developments of the Wankel engine are worthy of attention. 